\title{
A SERIES OF UNFORTUNATE EVENTS: COMMON SEQUENCING PATTERNS IN FINANCIAL CRISES
}

\author{
Carmen M. Reinhart \\ Working Paper 17941 \\ http://www.nber.org/papers/w17941 \\ NATIONAL BUREAU OF ECONOMIC RESEARCH \\ 1050 Massachusetts Avenue \\ Cambridge, MA 02138 \\ March 2012
}

This paper was prepared for the XIth Angelo Costa Lecture, Rome, October 5, 2011. The material is drawn from Carmen M. Reinhart and Kenneth S. Rogoff This Time is Different: Eight Centuries of Financial Folly (Princeton: Princeton University Press, 2009) and Carmen M. Reinhart, Jacob Kirkeegard, and Belen Sbrancia, Financial Repression Redux (2011). I wish to thank Vincent R. Reinhart and conference participants for helpful comments and suggestions. The views expressed herein are those of the author and do not necessarily reflect the views of the National Bureau of Economic Research.

NBER working papers are circulated for discussion and comment purposes. They have not been peerreviewed or been subject to the review by the NBER Board of Directors that accompanies official NBER publications.

(C) 2012 by Carmen M. Reinhart. All rights reserved. Short sections of text, not to exceed two paragraphs, may be quoted without explicit permission provided that full credit, including $\odot$ notice, is given to the source. 
A Series of Unfortunate Events:Common Sequencing Patterns in Financial Crises

Carmen M. Reinhart

NBER Working Paper No. 17941

March 2012

JEL No. E32,E44,E50,F30,F33,G01,N20

\begin{abstract}
$\underline{\text { ABSTRACT }}$
We document that the global scope and depth of the crisis the began with the collapse of the subprime mortgage market in the summer of 2007 is unprecedented in the post World War II era and, as such, the most relevant comparison benchmark is the Great Depression (or the Great Contraction, as dubbed by Friedman and Schwartz, 1963) of the 1930s. Some of the similarities between these two global episodes are examined but the analysis of the aftermath of severe financial crises is extended to also include the most severe post-WWII crises as well. As to the causes of these great crises, we focus on those factors that are common across time and geography. We discriminate between root causes of the crises, recurring crises symptoms, and common features (such as misguided financial regulation or inadequate supervision) which serve as amplifiers of the boom-bust cycle. There are recurring temporal patterns in the boom-bust cycle and their broad sequencing is analyzed.
\end{abstract}

Carmen M. Reinhart

Peterson Institute for International Economics

1750 Massachusetts Avenue, NW

Washington, DC 20036-1903

and CEPR

and also NBER

creinhart@piie.com 


\section{Introduction}

“Overindebtedness simply means that debts are out-of-line, are too big relative to other economic factors. It may be started by many causes, of which the most common appears to be new opportunities to invest at a big prospective profit... such as through new industries... Easy money is the great cause of over-borrowing."

\section{Irving Fisher (1933).}

This paper follows my remarks at the XIth Angelo Costa Lecture, Rome, October 5, 2011 and draws heavily from Reinhart and Rogoff (2009) and Reinhart, Kirkeegard, and Sbrancia (2011).

The issues I address fall into three broad areas or sections. ${ }^{2}$ The next section takes stock of the collateral damage, in terms of the incidence of banking crises and currency and crashes around the world, which followed the financial turmoil that began as the subprime crisis in the United States in the summer of 2007. Following a common pattern in history, the financial crash has more recently morphed into full fledged sovereign crises engulfing (to date), in varying degrees, Greece, Portugal, Ireland, Italy and Spain. ${ }^{3}$ Apart from its impact on domestic and international financial flows, not to mention the changes in the landscape of the financial industry, that this crisis has produced, the toll on the real economy has been great. The evolution of world trade helps to illustrate the breadth and depth of the economic downturn. Global equity prices have also followed a roller coaster pattern since the onset of crisis about four years ago. The evidence presented here, places these developments in a broader historical and international perspective that allows us to gauge the unusual severity of the unfolding global crisis. Section III dwells on the aftermath of severe financial crises, and speculates

\footnotetext{
${ }^{2}$ Reinhart and Rogoff will be henceforth referred to as RR.

${ }^{3}$ Reinhart and Rogoff (2011b).
} 
where we might be in the post-crisis cycle. The comparisons focus primarily on the housing and labor markets, where the aftereffects of the crises have tended to linger the longest. The fiscal implications and consequences of severe crises are discussed. Section IV poses the question of what causes these great crises and what factors make them more severe. The focus of this discussion is on causal factors that are common to severe financial crises across countries and across time rather than those that are idiosyncratic to the political and economic circumstances of the latest episode. The last section discusses on the high (and rapidly rising) levels of public sector indebtedness in nearly all the advanced economies and its implication for the "international financial architecture" in the form of financial repression in years to come.

\section{Taking stock: The global dimensions of the crisis}

\section{A global crisis index}

So, where are we in a historical global context? We present an index which proxies of world economic turbulence. These aggregate crisis indices are the time series shown for 1900-2010 in Figure 1 for the "World". The indices shown are weighted by a country's share in world GDP, as we have done for debt and banking crises. The 66country sample accounts for about 90 percent of world GDP. The country indices (without stock market crashes) are compiled from the time of independence (if after 1800) onward; the index that includes the equity market crashes is calculated based on data availability. While inflation and banking crises predate independence in many cases, a sovereign debt crisis (external or internal) is by definition not possible for a colony. In addition, numerous colonies did not always have their own currencies. The BCDI index 
stands for banking (systemic episodes only), currency, debt (domestic and external), and inflation crisis index. When stock market crashes are added (shown separately) to the $B C D I$ composite, we refer to it as the $B C D I+$

Figure 1 chronicles and summarizes the incidence, and to some degree the severity of varied crisis experience. A cursory inspection of the figure reveals a very different pattern for the pre- and post-WWII experience. The pre-war experience is characterized by frequent and severe crises episodes ranging from the banking-crisis driven "global" panic of 1907 to the debt and inflation crises associated with World War II and its aftermath. The only period during the post war that we see as high an incidence of crises is the fifties where, during World War II big countries -- Germany, Austria, Japan, Italy -- were in a state of default and remained so through the early fifties. Plus, of course, there were a lot of countries that had gone into default in the thirties that were still in default. But since the immediate aftermath of World War II, we had not seen a crisis this global in scope.

The sharp rise in the blue line (BCDI index) that we see in 2007 and more so in 2008 is mostly dominated by banking crises and also currency crashes. Indeed, a large share of countries in the fall of 2008 , had sufficiently large depreciations to classify as a currency crash (i.e., exchange rate depreciations exceeding 15 percent). The red line adds stock market crashes — which were ubiquitous in 2008-2009. No doubt, when the index is updated to reflect year-end 2011 price levels, it will reveal yet another wave of stock market crashes. 
Figure 1. Varieties of crises: World aggregate, 1900-2010

A composite index of banking, currency, sovereign default and, inflation crises, and stock market crashes (weighted by their share of world income)

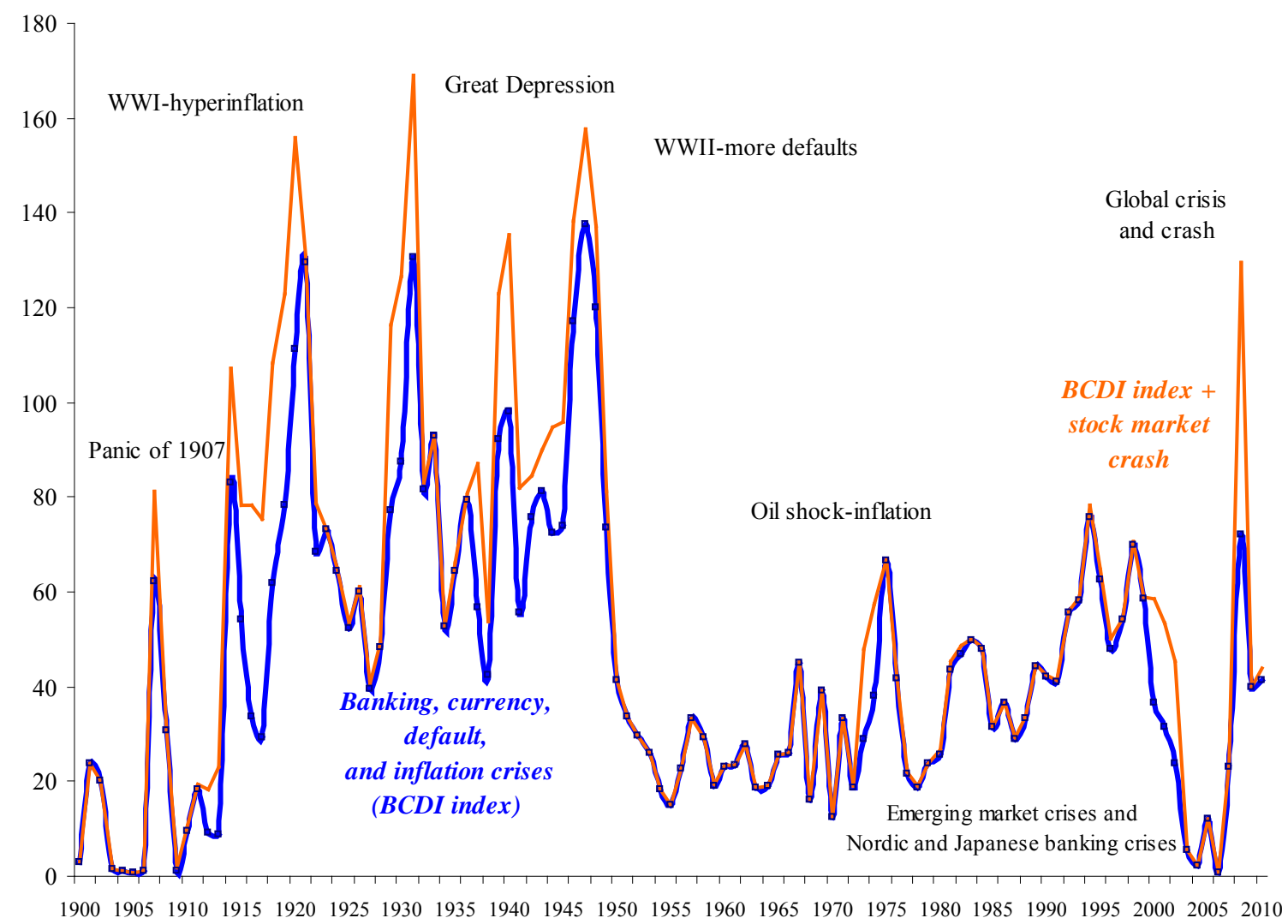

Notes: The banking, currency, default (domestic and external) and inflation composite (BCDI index) can take a value between 0 and 5 (for any country in any given year) depending on the varieties of crises taking place on a particular year. For instance, in 1998 the index took on a value of 5 for Russia, as there was a currency crash, a banking and inflation crisis, and a sovereign default on both domestic and foreign debt obligations. This index is then weighted by the country's share in world income. This index is calculated annually for the 66 countries in the sample for 1800-2010:6 (shown above for 1900-onwards). We have added, for the borderline banking cases identified in Laeven and Valencia (2010) for the period 2007-2010. In addition, we use the Barro and Ursua (2009) definition of a stock market crash for the 25 countries in their sample (a subset of the 66-country sample-except for Switzerland) for the period 1864-2006; we update their crash definition through June 2010, to compile our BCDI+ index. For the United States, for example, the index posts a reading of 2 (banking crisis and stock market crash) in 2008; for Australia and Mexico it also posts a reading of 2 (currency and stock market crash).

\section{World trade}

As to trade, we offer we offer an illustration of the evolution of trade during two global crises. Figure 2 plots the value of World merchandise exports for 1928-2010. The estimate for 2009 uses the actual year-end level for 2008 as the average for 2009; this 
yields a 9 percent year-over-year decline in 2009 , the largest one-year drop since $1938 .{ }^{4}$ Other large post-WWII declines are in 1952, during the Korean War and in 1982-1983, when recession hit the United States and a 1930s-scale debt crisis swept through the emerging world. Smaller declines occurred in 1958, the bottom of a recession in the United States, 1998 during the Asian financial crisis and in 2001, after September 11.

\footnotetext{
${ }^{4}$ While we have reliable trade data for a most countries during World War II, there are sufficient missing entries so as to make the calculation of the world aggregate not comparable to other years during 19401947.
} 
Figure 2. World export growth, 1928-2010

(annual percent change)

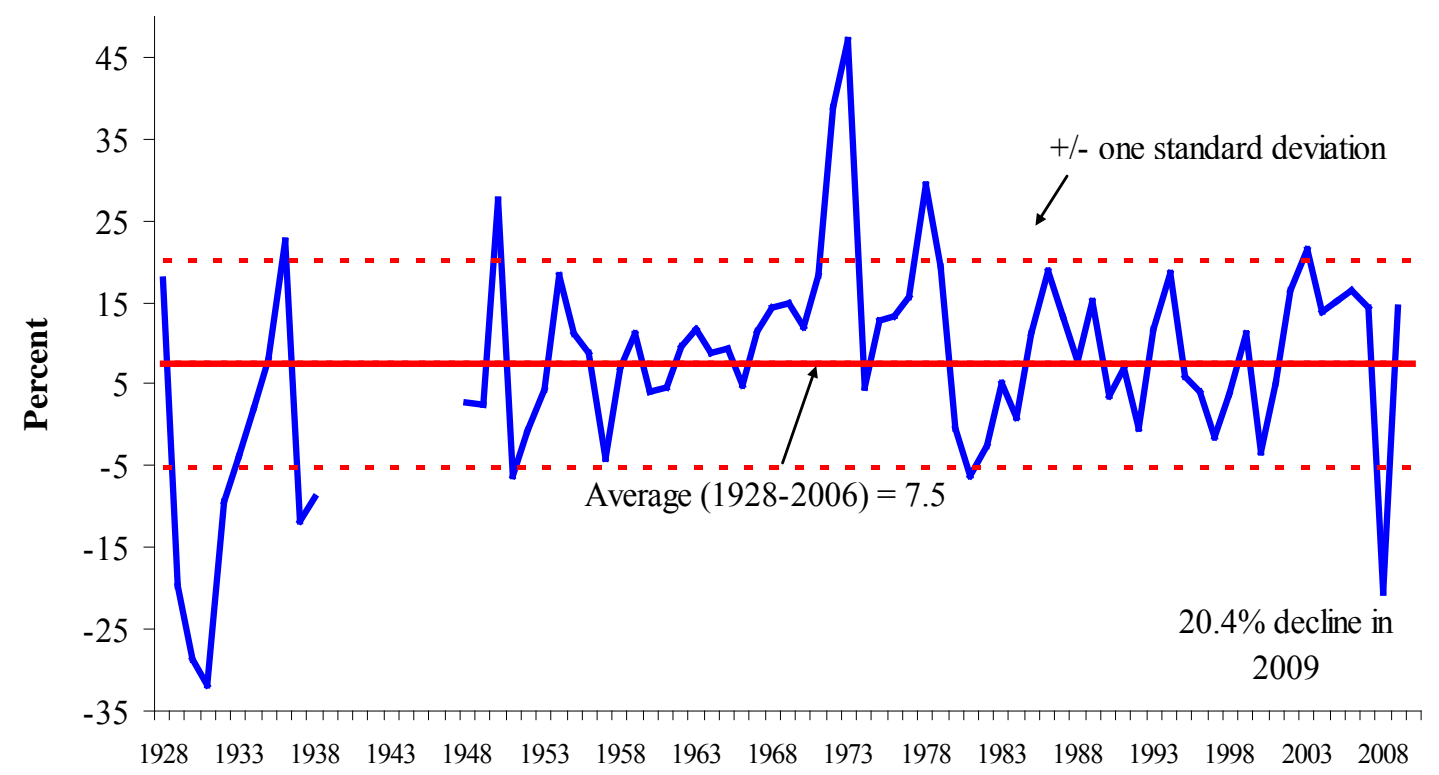

Sources: Global Financial Data (GFD), League of Nations, World Economic Survey (various issues), International Monetary Fund, World Economic Outlook, and the authors (see notes).

Notes: The estimate for 2010 is from the World Economic Outlook. The 20.4 percent year-over-year decline in 2010, is the largest post-war drop. Other large post-WWII declines are in 1952, during the Korean War and in 1982-1983, when recession hit the United States and a 1930s-scale debt crisis swept through the emerging world. Smaller declines occurred in 1958, the bottom of a recession in the United States, 1998 during the Asian financial crisis and in 2001, after September 11.

\section{The "big picture"}

In sum, Figures 1-2 highlight the breadth, depth, and internationally synchronous nature of the post-2007 financial crisis, especially in relation to the milder more scattered crises episodes of the post war landscape. Even "significant global" events, such as the break-down of the Bretton Woods system of fixed exchange rates, the oil shocks of the mid-1970s and the emerging market debt crisis of the early 1980s, pale in comparison in terms of the incidence of crises and impacts on the real economy. Indeed, the ouput declines registered in many advanced and emerging market economies in 2009 rank 
among the largest declines in the history of the national income accounts. In several countries, the declines in real GDP during the second great contraction (2008-2009) matched and even exceeded those recorded during severe "home grown" financial crises. This list includes such diverse countries (crisis year in parentheses) as Finland (1991); Mexico (1995); Singapore (1982); Spain (1977); Sweden (1991); Turkey (2001), among others.

Having suggested that the severity of this crisis is on a different scale from the post-war norm, it is logical sequel to expect that the aftermath of the crisis will, in all likelihood, also depart from the "standard" post-war recession-recovery pattern. To this end, the next section summarizes selected empirical findings of the RR study on the aftermath of severe financial crises.

\section{The Aftermath of Financial Crises}

Let me begin by observing that, as to the present conjuncture in the United States, the post-war recession experience should not be seen as an instructive benchmark for where we are at present or what we should expect. The average NBER post-war recession lasts less than a year. The worst one lasted 16 months. We passed those milestones.

Broadly speaking, financial crises are protracted affairs. More often than not, the aftermath of severe financial crises share three characteristics. First, asset market collapses are deep and prolonged. Real housing price declines average 35 percent stretched out over six years. Second, the aftermath of banking crises is associated with profound declines in output and employment. The unemployment rate rises an average of 
7 percentage points over the down phase of the cycle, which lasts on average over four years. Third, the real value of government debt tends to explode, rising an average of 86 percent in the major post-World War II episodes. Interestingly, the main cause of debt explosions is not the widely cited costs of bailing out and recapitalizing the banking system. In fact, the biggest driver of debt increases is the inevitable collapse in tax revenues that governments suffer in the wake of deep and prolonged output contractions.

\section{Unemployment}

To illustrate, Figure 3 examines unemployment rates in the wake of the 14 worst financial crises in the post war. And what the left panel shows is the increase in the unemployment rate from the low point to the high point. So, it's the cumulative increase in unemployment for that particular crisis. What the right panel shows is the duration in years of the time it takes to go from the lowest unemployment level to the highest. On average from bottom to peak, unemployment increases by about 7 percentage points during the worst financial crises. In the U.S. context, low point in unemployment in 2006 was around 4 percent-a 7 percentage point increase would take it to 11 percent. The average duration (bottom to peak) is 4.8 years.

These indices are the official unemployment rates; we are now all aware of more encompassing measures, such as U6 that are much higher than this when you take into account underemployment and so on. That's not reflected in these numbers.

To reiterate, recovery in the aftermath of severe financial crises are protracted affairs, in general. 


\section{Figure 3}

Past Unemployment Cycles and Banking Crises: Trough-to-peak

Percent Increase in the Unemployment Rate (left panel) and Years Duration of Downturn (right panel)
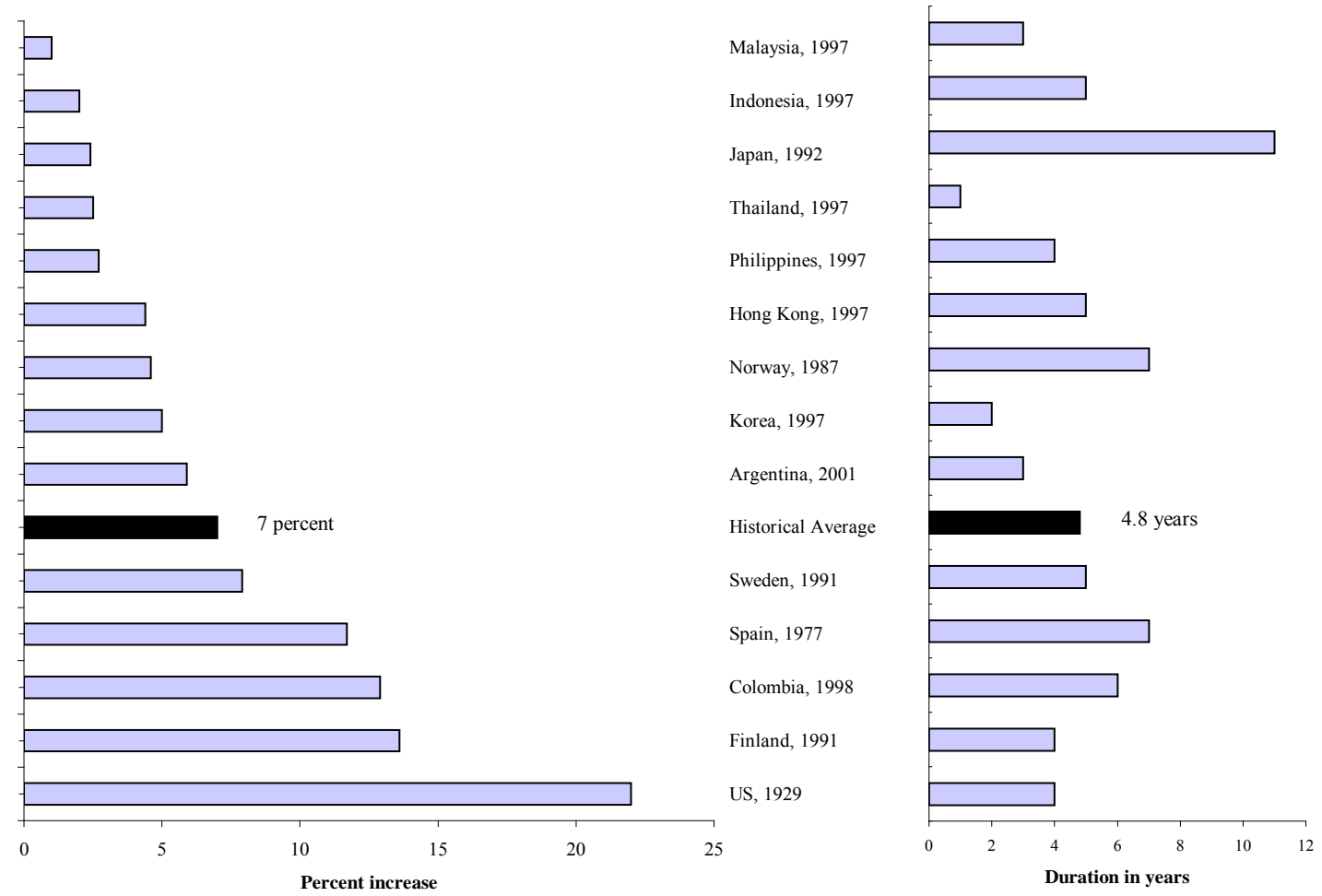

Sources: OECD, IMF, Historical Statistics of the United States (HSOUS), various country sources, and authors' calculations.

Notes: Each banking crisis episode is identified by country and the beginning year of the crisis. Only major (systemic) banking crises episodes are included, subject to data limitations. The historical average reported does not include ongoing crises episodes.

\section{Public debt}

Where there is a substantial economic downturn, high and rising unemployment, and imploding real estate prices - major fiscal consequences should be expected. Not surprisingly, the true legacy of a major financial crisis is more government debt. Figure 4 shows the rise in real government debt in the three years following a banking crisis. The deterioration in government finances is striking, with an average debt rise of over 86 percent. We look at percentage increase in debt, rather than debt-to-GDP, because sometimes steep output drops would complicate interpretation of debt-GDP ratios. As RR 
(2009) note, the characteristic huge buildups in government debt are driven mainly by sharp falloffs in tax revenue.

Importantly, however, another major contributor to the public debt buildup in past crises as well as the current one if the fact that private debts before a crisis become public debts afterwards. Nowhere is this pattern more evident in recent history that in Ireland, where the debt/GDP of general government stood at around 25 percent in 2007 and has since more than quadrupled. ${ }^{5}$ In the United States, in early 2010 the transfer of the two mortgage giants, Fannie and Freddie, added 25 percent to the general government's debtto-GDP ratio.

\footnotetext{
${ }^{5}$ Reinhart (2010) documents numerous episodes where private debts ended up in the public sector balance sheet.
} 
Figure 4

\section{Cumulative increase in real public debt in the three years following the banking crisis}

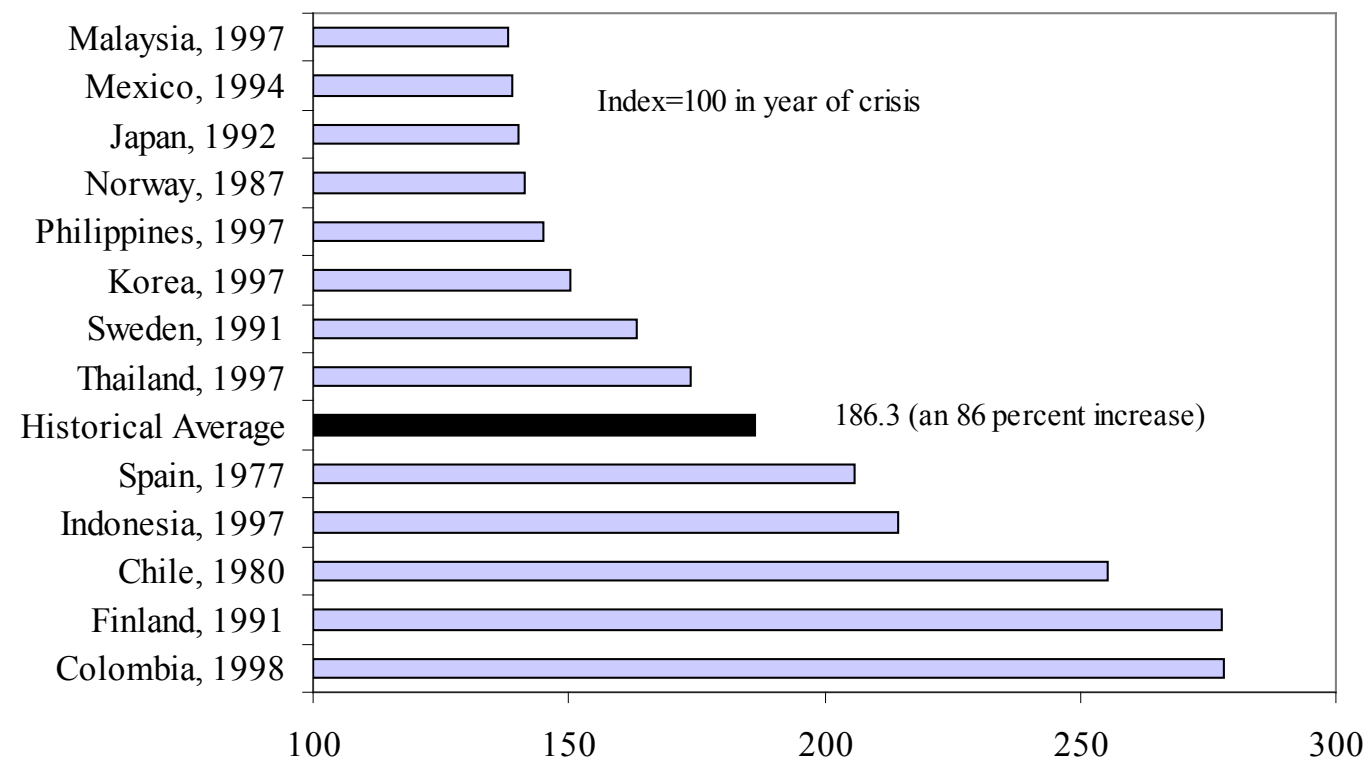

Sources: Reinhart and Rogoff (2008b) and sources cited therein.

Notes: Each banking crisis episode is identified by country and the beginning year of the crisis. Only major (systemic) banking crises episodes are included, subject to data limitations. The historical average reported does not include ongoing crises episodes, which are omitted altogether, as these crises begin in 2007 or later, and debt stock comparison here is with three years after the beginning of the banking crisis.

\section{Causes, Symptoms, and Amplifiers of Financial Crises}

As to the causes of these great crises, we next focus on those factors that are common across time and geography; we discriminate between root causes of the crisis, its symptoms, and features such as financial regulation which serve as amplifiers of the boom-bust cycle. Pertinent to the globalization theme of this conference, the discussion begins with the link between financial liberalization (internal and external), the financial innovation and credit booms these spawn and banking crises.

\section{The roots}


There is a striking correlation between freer capital mobility and the incidence of banking crises, as shown in Figure 5. Periods of high international capital mobility have repeatedly produced international banking crises, not only famously as they did in the 1990s, but historically. The figure plots a three-year moving average of the share of all countries experiencing banking crises on the right scale. On the left scale, we graph the index of capital mobility, due to Obstfeld and Taylor (2004), updated and back cast using their same design principle, to cover our full sample period. While the ObstfeldTaylor index may have its limitations, we feel it nevertheless provides a concise summary of complicated forces by emphasizing de facto capital mobility based on actual flows.

For the post-1970 period, Kaminsky and Reinhart (1999) present formal evidence on the links of crises with financial liberalization. In 18 of the 26 banking crises they study, the financial sector had been liberalized within the preceding five years, usually less. In the 1980s and 1990s most liberalization episodes were associated with financial crises of varying severity. Only in a handful of countries (for instance, Canada) did financial sector liberalization proceed smoothly. Specifically, the paper presents evidence that the probability of a banking crisis conditional on financial liberalization having taken place is higher than the unconditional probability of a banking crisis. 
Figure 5. Capital Mobility and the Incidence of Banking Crises:

All Countries, 1800-2010

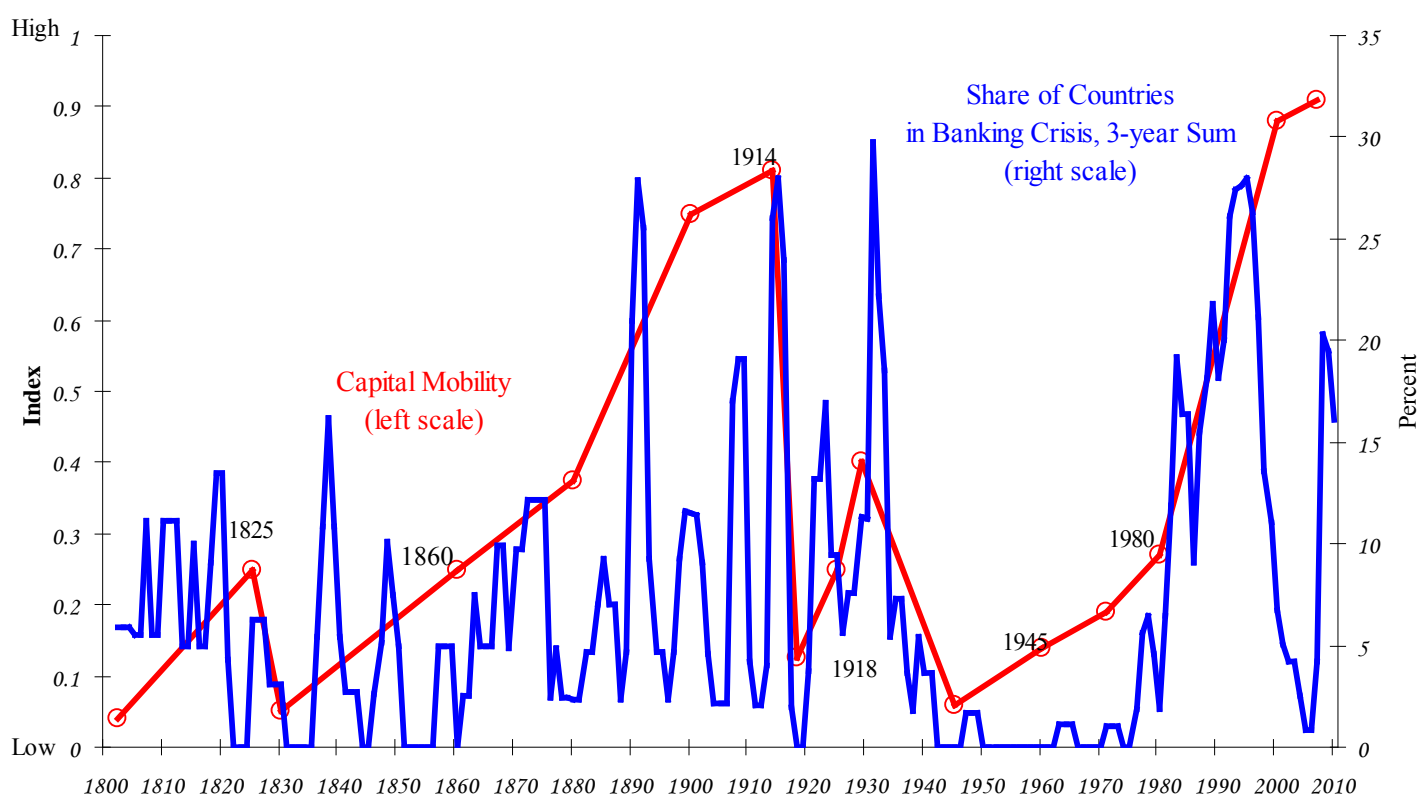

Sources: Bordo et al. (2001), Caprio et al. (2005), Kaminsky and Reinhart (1999), Laeven and Valencia (2010), Obstfeld and Taylor (2004), and these authors.

Notes: This sample includes all countries (even those not in our core sample of 66). The full listing of banking crises dates are shown in Appendix II. On the left scale, we updated our favorite index of capital mobility, admittedly arbitrary, but a concise summary of complicated forces. The smooth red line shows the judgmental index of the extent of capital mobility given by Obstfeld and Taylor (2004), back cast from 1800 to 1859 using their same design principle.

\section{The setting}

Across countries and over the centuries, economic crises of all type follow a similar pattern. An innovation emerges. Sometimes it is a new tool of science of industry, such as the diving bell, steam engine, or the radio. Sometime it is a tool of financial engineering, such as the joint-stock company, junk bonds, or collateralized debt obligations. These usually accompany or are a direct result of financial liberalization, as described above. Investors may be wary at first, but then they see that extraordinary returns appear available on these new instruments and they rush in. Financial intermediaries_-banks and investment companies_-stretch their balance sheets so as not to be left out. The upward surge in asset prices continues, and that generation of financial 
market participants concludes that rules have been rewritten: Risk has been tamed, and leverage is always rewarded. All too often, policy makers assert that the asset-price boom is a vote of confidence on their regime - that "this time is different". Only seldom, to my knowledge, do they protest that perhaps the world has not changed and that the old rules of valuation still apply.

But the old rules do apply. The asset price rise peters out, sometimes from exhaustion on its own or sometimes because of a real shock to the economy. This exposes the weaknesses of the balance sheets of those who justified high leverage by the expectation of outsized capital gains. Many financial firms admit losses, and some ultimately fail. All those financial firms hunker down, constricting credit availability in an effort to slim their balance sheets. With wealth lower and credit harder to get, economic activity typically contracts. Only after the losses are flushed out of the financial system and often with the encouragement of lagging monetary and fiscal ease does the economy recover.

\section{The symptoms}

The recurring historical pattern described above is associated with some welldefined symptoms. I will focus here on a few of the symptoms or quantitative parallels (those listed in Table 1) that have been present during the current crisis in several countries and that we have seen systematically in numerous earlier crises in advanced and emerging market economies alike. ${ }^{6}$ Specifically, large capital inflows, sharp housing and equity price run-ups lead the "leading indicator" group. So have been surges in private

\footnotetext{
${ }^{6}$ These and other economic and financial indicators are analyzed in detail in Kaminsky and Reinhart (1999).
} 
domestic and external debts. These symptoms are quantifiable, unlike the more nebulous amplifiers that are discussed in the remainder of this section.

Table 1. Quantitative antecedents of financial crises:

The "lead" of the leading indicators

Large capital inflows

Sharp run-ups in equity prices

Sharp run-ups in housing prices

Inverted V-shaped growth trajectory

Marked rise in indebtedness

If we were to quantify periods of capital flow bonanzas -- periods where capital

inflows are unusually large -- who comes up on the radar screen prior to the 2007-2009

crisis? As Reinhart and Reinhart (2008) document, in addition to the U.S. and the U.K., the other names that are listed there -- Spain, Italy, Iceland, Ireland -- are all countries that have had a period where the large capital inflows ended badly. Capital inflows facilitate domestic lending, fuel asset prices, and in most instances increase the indebtedness of the private sector, the public sector (if the government behaves procyclically), or both. 
Table 2 Capital Inflows Typically Surge Ahead of Financial Crisis

\begin{tabular}{lccc} 
Countries with recent notable capital inflows & 2006 & 2007 & 2008 \\
\hline \hline & & & \\
Bulgaria & $\sqrt{ }$ & $\sqrt{ }$ & $\sqrt{ }$ \\
Iceland & $\sqrt{ }$ & $\sqrt{ }$ & $\sqrt{ }$ \\
Italy & $\sqrt{ }$ & $\sqrt{ }$ & $\sqrt{ }$ \\
Jamaica & $\sqrt{ }$ & $\sqrt{ }$ & $\sqrt{ }$ \\
Latvia & $\sqrt{ }$ & $\sqrt{ }$ & $\sqrt{ }$ \\
New Zealand & $\sqrt{ }$ & $\sqrt{ }$ & $\sqrt{ }$ \\
Pakistan & $\sqrt{ }$ & $\sqrt{ }$ & $\sqrt{ }$ \\
Romania & $\sqrt{ }$ & $\sqrt{ }$ & $\sqrt{ }$ \\
Slovenia & $\sqrt{ }$ & $\sqrt{ }$ & $\sqrt{ }$ \\
South Africa & $\sqrt{ }$ & $\sqrt{ }$ & $\sqrt{ }$ \\
Spain & $\sqrt{ }$ & $\sqrt{ }$ & $\sqrt{ }$ \\
Turkey & $\sqrt{ }$ & $\sqrt{ }$ & $\sqrt{ }$ \\
United Kingdom & $\sqrt{ }$ & $\sqrt{ }$ & $\sqrt{ }$ \\
United States & $\sqrt{ }$ & $\sqrt{ }$ & $\sqrt{ }$
\end{tabular}

Source: Reinhart and Reinhart (2008).

Notes: For the full list of recent bonanza episodes see the paper.

There is a sense that the U.S. housing price bubble during 2000-2006 (primarily)

is both unique and unprecedented. The magnitude of the bubble is certainly

unprecedented to the United States--at least during the past century for which we have

comparable data. However, in a broader global context, the sub-prime bubble is neither

unique to the U.S. nor it magnitudes out of line with other real estate bubbles that have also ended equally lamentably in financial crises.

Figure 6 compares the run-up in housing prices over 2002-2006. The red bar highlights the countries that had systemic banking crises. While the housing bubble in the run-up to the subprime crisis in the US is now infamous, the chart illustrates that the pattern of a housing price boom ahead of the financial crisis was hardly unique to the US case. Indeed, it is fully compatible with the "standard" antecedents of a crisis, as discussed demonstrated in Reinhart and Rogoff (2009). 
The boom in real housing prices (or real estate, and other asset prices, more broadly) is fueled by ample domestic credit availability, large capital inflows, and the easy liquidity environment that, and that this facilitates the boom. Coupling the ample liquidity environment with the presumption that this time is different and that the old rules of valuation do not apply, then you have the makings or the ingredients for a crisis.

As to growth (inverted V-shaped pattern) -- growth does very well ahead of the crisis when credit is ample and wealth effects are positive (as asset prices climb) and falls subsequently. For further evidence the reader is referred to RR.

I cannot stress enough the importance of the last entry in Table 1, a marked rise in indebtedness. Rising indebtedness can be domestic, external or both. In can be private, public or both. Any combination of these forms of rising indebtedness has been a hallmark of the pre-crisis period as far back as our data can take us. Perhaps Iceland illustrates this point in its most extreme form, as external debts rise from about 90 percent of GDP in 2000 to well over 900 percent of GDP in 2009. It is worth noting that stating that there are capital inflows is usually a different of observing that a country is borrowing from the rest of the world. 
Figure 6. Percent Change in Real Housing Prices (2002-2006) and Banking Crisis

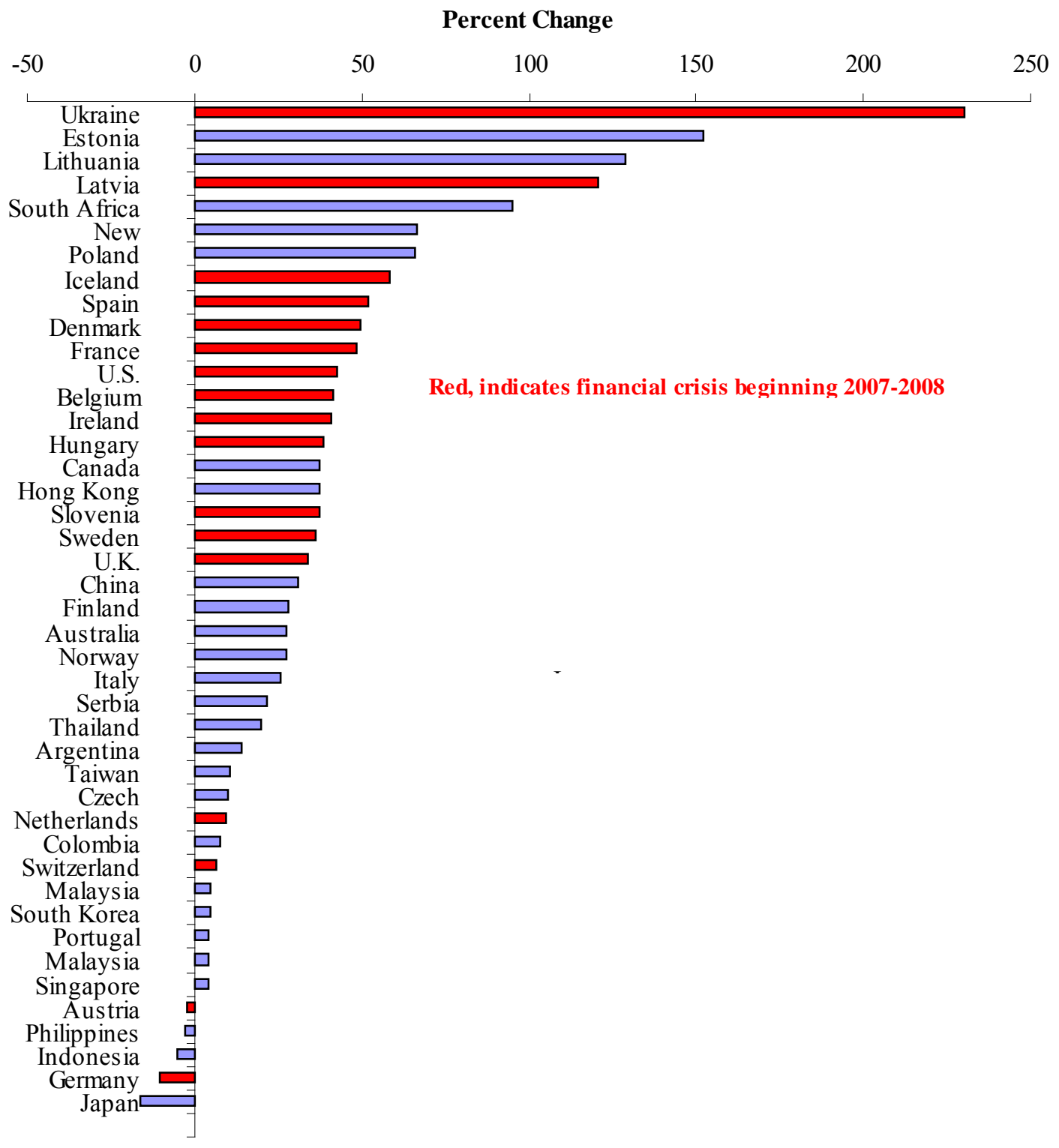

Source: Reinhart and Rogoff (2009). 


\section{The "amplifiers"}

The list (shown on Table 3) of what I have dubbed the "usual suspects" (which ranges from pro-cyclical macroeconomic policies to overvalued currencies and myopic rating agencies) despite its breadth is not meant to be exhaustive. It is a list that has withstood the test of time, as several of these amplifiers come up on a recurring and it is those are not unique to the United States subprime crisis. Countless case studies of banking crises, across countries and time (see references in RR) list these factors on a recurring basis--often blamed as underlying causes of the crises. However, it is my view that these factors exacerbate both the boom and bust phases of the crisis cycle. For example, the stylized evidence presented in Caprio and Klingebiel (1996) suggests that inadequate regulation and lack of supervision at the time of the liberalization may play a key role in explaining why deregulation and banking crises are so closely entwined. But

it is difficult to explain a cycle with a constant. Supervision may have always been lacking and the regulations ill defined. But such deficiencies may have limited consequences when credit conditions are tight (or in the case of emerging markets when access to international capital markets is not possible). If, on the other hand, financial liberalization (domestic an external) create lending possibilities that did not exist before, then inadequate supervision can make a bad lending scenario worse. Outright fraud, (often through connected lending) which crops up as another hardy perennial in studies of the run-up to crises works the same way.

The procyclicality of credit ratings (both at the sovereign and corporate levels, see Reinhart, 2002) also acts to amplify the cycle of lending and subsequent default and 
crash. Overvalued currencies are a magnet for capital inflows while procyclical fiscal policies add to the surge in borrowing during the boom phase of the cycle.

Far from being mutually exclusive many, if not most of the items in this list are present simultaneously in the most severe financial crises through out history.

Table 3. Amplifliers of boom-bust cycles: The usual suspects

\author{
Procyclical macroeconomic policies \\ Hidden debts (implicit guarantees) \\ Overvalued currencies \\ Poor regulation \\ Even worse supervision \\ Outright fraud \\ Myopic credit rating agencies
}

\title{
5. A digression on the sequencing of crises
}

Just as financial crises have common macroeconomic antecedents in asset prices, economic activity, external indicators and so on, so common patterns appear in the sequencing (temporal order) in which crises unfold. Obviously not all crises escalate to the extreme outcome of a sovereign default. Yet, advanced economies have not been exempt from their share of currency crashes, bouts of inflation, severe banking crises, and, in an earlier era, even sovereign default. The point of this short digression is to note that the long debt cycle we have discussed does not necessarily end with a banking crisis - more bad news usually follows — a stylized fact that should be kept in mind when trying to make sense of the current conjuncture.

Investigating what came first, banking or currency crises, was a central theme of Kaminsky and Reinhart's (1999) "twin crises" work; they also concluded that financial liberalization often preceded banking crises; indeed, it helped predict them. DemirgüçKunt and Detragiache (1998), who employed a different approach and a larger sample, 
arrived at the same conclusion. Reinhart (2002) examined the currency crash-external default link. Our work here has investigated the connections between domestic and external debt crises, inflation crises and default (domestic or external), and banking crises and external default. ${ }^{7}$ Figure 7 maps out a "prototypical" sequence of events yielded by this literature.

As Diaz-Alejandro (1985) narrates in his classic paper about the Chilean experience of the late 1970s and early 1980s, "Goodbye Financial Repression, Hello Financial Crash," financial liberalization simultaneously facilitates banks' access to external credit and more risky lending practices at home. After a while, following a boom in lending and asset prices, weaknesses in bank balance sheets become manifest and problems in the banking sector begin. ${ }^{8}$ Often these problems are more advanced in the shakier institutions (such as finance companies) than in the major banks.

The next stage in the crisis unfolds when the central bank begins to provide support for these institutions by extending credit to them. If the exchange rate is heavily managed (it does not need to be explicitly pegged), a policy inconsistency arises between supporting the exchange rate and acting as lender of last resort to troubled institutions. The very numerous experiences in these studies suggest that (more often than not) the exchange rate objective is subjugated to the lender of last resort role of the central bank. Even if central bank lending to the troubled financial industry is limited in scope, the central bank may be more reluctant to engage in an "interest rate defense" policy to

\footnotetext{
${ }^{7}$ Reinhart and Rogoff (2004) also examined the relationship between currency crashes and inflation as well as the currency crash-capital control (specifically, dual or multiple exchange rates) timing.

${ }^{8}$ In contrast to other studies of banking crises, Kaminsky and Reinhart (1999) provide two dates for each banking crisis episode - the beginning of a banking crisis and the later peak.
} 
defend the currency than would be the case if the financial sector were sound. This brings the sequence illustrated in Figure 7 to the box labeled currency crash.

\section{FIGURE 7 The sequencing of crises: A prototype}

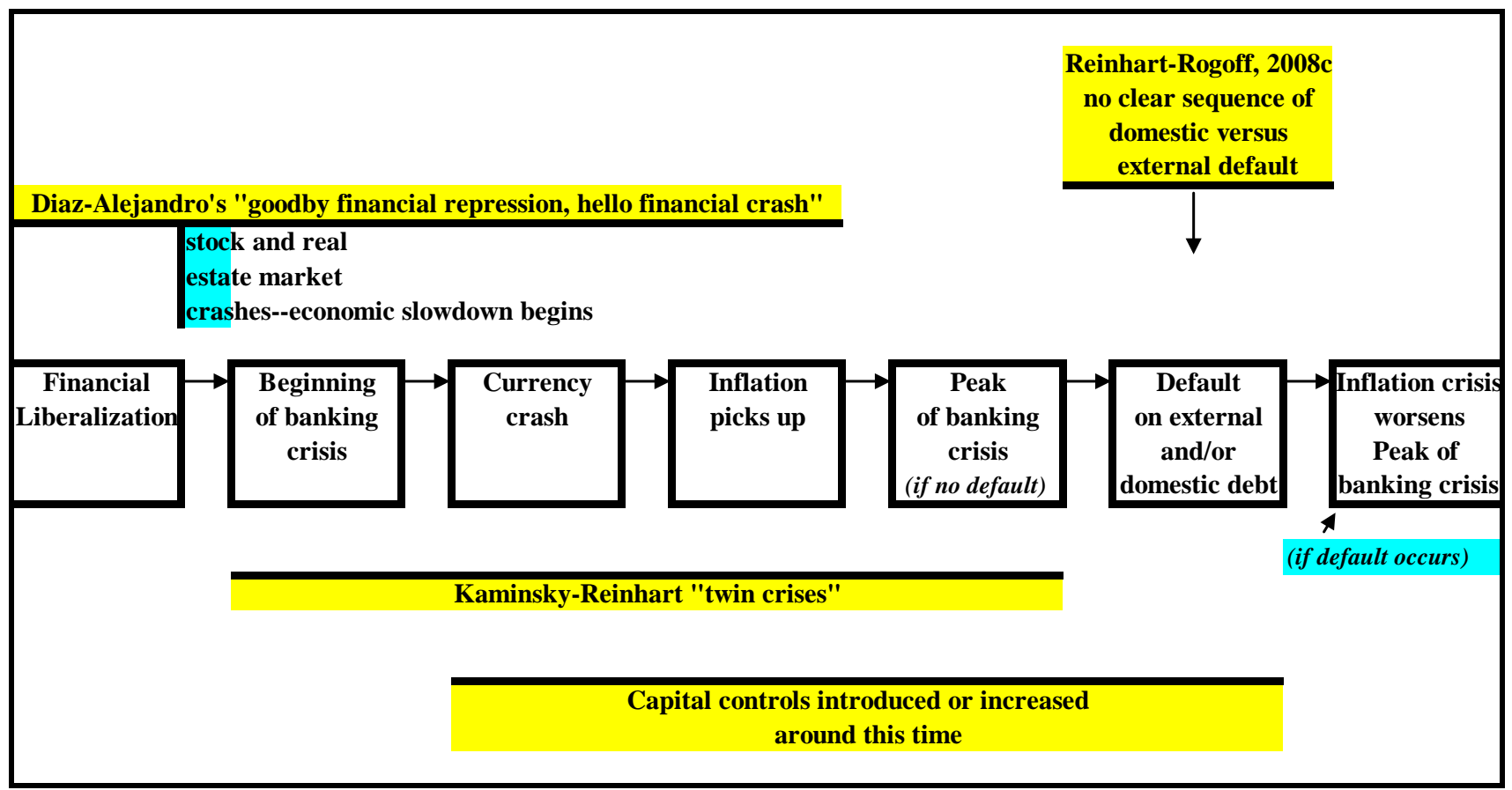

Sources: Authors' introspection based on empirical evidence from: Demirgüç-Kunt and Detragiache (1998), Diaz-Alejandro (1985), James (2002), Kaminsky and Reinhart (1999), Kindelberger (1985), Reinhart (2002), Reinhart and Rogoff (2004 and 2008c), among others.

The depreciation or devaluation, as the case may be, complicates the situation in (at least) three dimensions: (a) it exacerbates the problem of the banks who have borrowed in a foreign currency, worsening currency mismatches; (b) inflation usually worsens (The extent to which the currency crisis translates into higher inflation is highly uneven across countries, as countries with a history of very high and chronic inflation usually have a much higher and faster pass-through from exchange rates to prices); and (c) if the government has foreign currency-denominated debt, the currency depreciation increases the odds of an external and domestic default. 
At this stage, the banking crisis either peaks following the currency crash, if there is no sovereign credit crisis, or keeps getting worse as the crisis mounts and the economy marches toward a sovereign default (the next box in Figure 7).

This is a very common pattern in the sequencing of crises. Notice the first entry there has financial liberalization. And financial liberalization is really not just liberalization proper, but big innovation, creations of new market. In the current conjuncture, the creation or the growth of securitization of mortgages is a big factor. Notice, perhaps more grimly, that the last entry is a debt crisis, which brings me to my remarks on debt resolution.

\section{From Goodbye Financial Repression, Hello Financial Crash to Goodbye Financial Crash-Hello Financial Repression?}

Periods of high indebtedness have historically been associated with a rising incidence of default or restructuring of public and private debts. Sometimes the debt restructuring is subtle and takes the form of "financial repression." In the heavily regulated financial markets of the Bretton Woods system, a variety of restrictions facilitated a sharp and rapid reduction in public debt/GDP ratios from the late 1940s to the 1970s. Reinhart, Kirkeegard, and Sbrancia (2011) document the resurgence of financial repression in the wake of the ongoing financial crises and the accompanying surge in public debts in advanced economies. This cycle in financial regulation, is perhaps the last box in the flow chart shown in Figure 7.

In light of the record or near-record levels of public and private debt, deficit/debt reduction strategies are likely to remain at the forefront of policy discussions in most of 
the advanced economies for the foreseeable future. ${ }^{9}$ Throughout history, debt/GDP ratios have been reduced by (i) economic growth; (ii) a substantive fiscal adjustment/austerity plans; (iii) explicit default or restructuring of private and/or public debt; (iv) a sudden surprise burst in inflation; and (v) a steady dosage of financial repression that is accompanied by an equally steady dosage of inflation. (Financial repression is defined in Box 1) It is critical to clarify that options (iv) and (v) are only viable for domesticcurrency debts (the euro area is a special hybrid case). Since these debt-reduction channels are not necessarily mutually exclusive, historical episodes of debt reduction have owed to a combination of more than one of these channels.

Financial repression is most successful in liquidating debts when accompanied by a steady dose of inflation. Low nominal interest rates help reduce debt servicing costs while a high incidence of negative real interest rates liquidates or erodes the real value of government debt. Inflation need not take market participants entirely by surprise and, in effect, it need not be very high (by historic standards).

\section{Financial repression defined}

Financial repression includes directed lending to the government by captive domestic audiences (such as pension funds or domestic banks), explicit or implicit caps on interest rates, regulation of cross-border capital movements, and (generally) a tighter connection between government and banks, either explicitly through public ownership of some of the banks or through heavy "moral suasion". Financial repression is also sometimes associated with relatively high reserve requirements (or liquidity

\footnotetext{
${ }^{9}$ See Reinhart and Rogoff (2010).
} 
requirements), securities transaction taxes, prohibition of gold purchases (as in the US from 1933 to 1974), or the placement of significant amounts of government debt that is nonmarketable.

In the current policy discussion, financial repression issues come under the broad umbrella of "macroprudential regulation."

We suggest that the combination of high public and private debts in the advanced economies (and the attendant pressures towards creating captive audiences for government debt) and the perceived dangers of currency misalignments and overvaluation in emerging markets facing surges in capital inflows (and, thus, the pressures towards currency intervention and capital controls) interact to produce a "home bias" in finance and a resurgence of financial repression. It is not called financial repression but unfolds in the context of "macroprudential regulation."

Succinctly, while emerging markets may increasingly look to financial regulatory measures to keep international capital "out" (especially as the expansive monetary policy stance of the US and others persists), advanced economies have incentives to keep capital "in" and create a domestic captive audience to facilitate the financing for the high existing levels of public debt. Concerned about potential overheating, rising inflationary pressures and the related competitiveness issues, emerging market economies are altering the regulatory frameworks that deter cross-border financial flows in their eternal quest for higher yields. This offers advanced and emerging market economies the common ground of agreeing to increased regulation and/or restrictions on international financial flows and, more broadly, the return to more tightly regulated domestic financial environmentoften referred to as "financial repression." 


\section{Negative real interest rates during 1945-1980 and again post-2008}

One of the main goals of financial repression is to keep nominal interest rates lower than would otherwise prevail. This effect, other things equal, reduces the governments' interest expenses for a given stock of debt and contributes to deficit reduction. However, when financial repression produces negative real interest rates and reduces or liquidates existing debts, it is a transfer from creditors (savers) to borrowers (in the historical episode documented in Reinhart and Sbrancia, 2011 and summarized here--the government).

The financial repression tax has some interesting political-economy properties. Unlike income, consumption, or sales taxes, the "repression" tax rate (or rates) are determined by financial regulations and inflation performance that are opaque to the highly politicized realm of fiscal measures. Given that deficit reduction usually involves highly unpopular expenditure reductions and (or) tax increases of one form or another, the relatively "stealthier" financial repression tax may be a more politically palatable alternative to authorities faced with the need to reduce outstanding debts.

Liberal capital-market regulations and international capital mobility reached their heyday prior to World War I under the gold standard. However, the Great Depression, followed by World War II, put the final nails in the coffin of laissez-faire banking. It was in this environment that the Bretton Woods arrangement of fixed exchange rates and tightly controlled domestic and international capital markets was conceived. The result was a combination of very low nominal interest rates and inflationary spurts of varying 
degrees across the advanced economies. ${ }^{10}$ The obvious results were real interest rates-whether on treasury bills (Figure 8), central bank discount rates, deposits or loans - that were markedly negative during 1945-1946.

For the next 35 years or so, real interest rates in both advanced and emerging economies would remain consistently lower than the eras of freer capital mobility before and after the financial repression era. In effect, real interest rates were, on average negative. Binding interest rate ceilings on deposits (which kept real ex-post deposit rates even more negative than real ex-post rates on treasury bills) "induced" domestic savers to hold government bonds. What delayed the emergence of leakages in the search for higher yields (apart from prevailing capital controls) was that the incidence of negative returns on government bonds and on deposits was (more or less) a universal phenomenon at this time. The frequency distributions of real rates for the period of financial repression (1945-1980) and the years following financial liberalization shown in Figure 8 , highlights the universality of lower real interest rates prior to the 1980 s and the high incidence of negative real interest rates.

A striking feature of Figure 8, however, is that real ex-post interest rates (shown for treasury bills) for the advanced economies have, once again, turned increasingly negative since the outbreak of the crisis. Real rates have been negative for about one half of the observations and below one percent for about 82 percent of the observations. This turn to lower real interest rates has materialized despite the fact that several sovereigns

\footnotetext{
${ }^{10}$ The advanced economy aggregate is comprised of: Australia, Belgium, Canada, Finland, France, Germany, Greece, Ireland, Italy, Japan, New Zealand, Sweden, the United States, and the United Kingdom. Interest rates for 2011 only reflect monthly observations through February.
} 
have bee teetering on the verge of default or restructuring (with the attendant higher risk premia). Real ex-post central bank discount rates and bank deposit rates (not shown here) have also become markedly lower since 2007.

No doubt, a critical factor explaining the high incidence of negative real interest rates in the wake of the crisis in the aggressively expansive stance of monetary policy (and more broadly, official central bank intervention) in many advanced and emerging economies during this period. This raises the broad question of to what extent current interest rates reflect market conditions versus the stance of official large players in financial markets. A large role for non-market forces in interest rate determination is a key feature of financial repression. 
Figure 8: Real Interest Rates Frequency Distributions: Advanced Economies, 1945-2011 Treasury bill rates

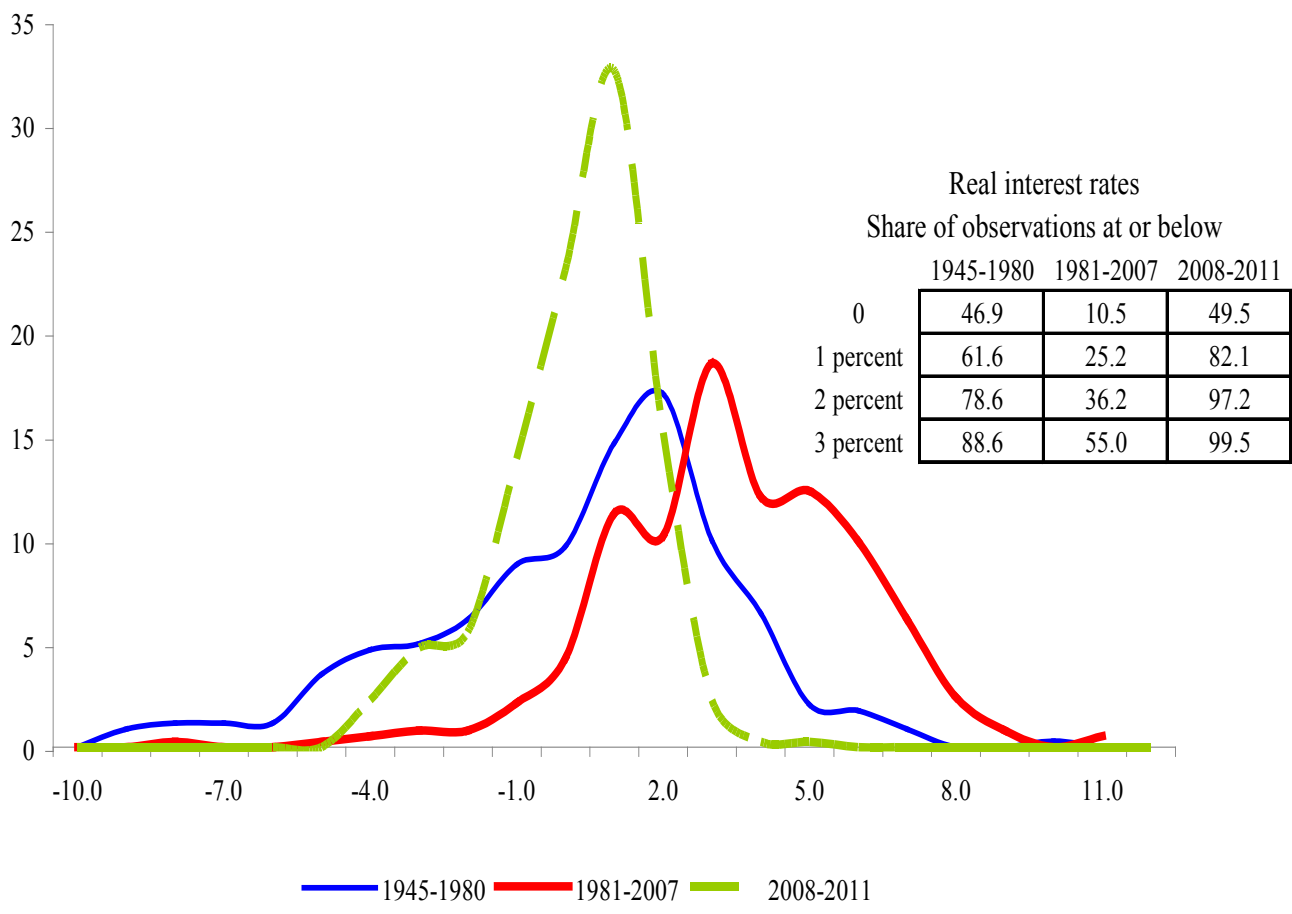

Sources: Reinhart and Sbrancia (2011), International Financial Statistics, International Monetary Fund, various sources listed in the Data Appendix, and authors' calculations.

Notes: The advanced economy aggregate is comprised of: Australia, Belgium, Canada, Finland, France, Germany, Greece, Ireland, Italy, Japan, New Zealand, Sweden, the United States, and the United Kingdom. Interest rates for 2011 only reflect monthly observations through February. 


\section{Concluding reflections}

I have already discussed the consequences of high public and private debts in the advanced economies and the attendant pressures towards financial repression to ease the burden of debt servicing. Not discussed here but a re-enforcing trend isthe perceived dangers of currency misalignments and overvaluation in emerging markets, and the attendant pressures towards currency intervention and capital controls - connected to the broader issue of "macroprudential regulation" a part of the evolving trend toward greater financial repression.

The two sets of pressures on central banks, in the North and South, are complementary. While emerging markets may increasingly look to financial regulatory measures to keep international capital "out" (especially as the expansive monetary policy stance of the US and Europe persists-as it is likely), advanced economies have incentives to keep capital "in" and create a domestic captive audience to facilitate the financing for the high existing levels of public debt. Concerned about potential overheating, rising inflationary pressures and the related competitiveness issues, emerging market economies may welcome changes in the regulatory landscape that keep financial flows at home rather than let them spill across borders. This offers advanced and emerging market economies the common ground of agreeing to increased regulation and/or restrictions on international financial flows and, more broadly, the return to more tightly regulated domestic financial environment- "financial repression."

The scenario sketched here entails both financial de-globalization (the reappearance of home bias in finance) and the re-emergence of more heavily regulated domestic financial markets. As some of these trends are already unfolding in individual 
countries, it is a useful exercise to examine these developments as part of a broader global picture. 


\section{References}

Bayoumi,Tamim, "Saving-Investment Correlations: Immobile Capital, Government Policy, or Endogenous Behavior”, IMF Staff Papers, 37 (2), June 1990, 360-387.

Bordo, Michael, Barry Eichengreen, Daniela Klingebiel, and Maria Soledad MartinezPeria, "Is the Crisis Problem Growing More Severe?" Economic Policy 16, April 2001, 51-82.

Bordo, Michael and Marc Flandreau, "Core, Periphery, Exchange Rate Regimes, and Globalization," in M. Bordo, A. Taylor and J. Williamson (eds.), Globalization in Historical Perspective, (Chicago: University of Chicago Press for National Bureau of Economic Research, 2003), 417-472.

Caprio, Gerald, Jr. and Klingebiel, Daniela, "Episodes of Systemic and Borderline Financial Crises," http://go.worldbank.org/5DYGICS7B0 (Dataset 1), January 2003.

Caprio, Gerald, Jr. and Klingebiel, Daniela, "Bank Insolvency: Bad Luck, Bad Policy, or Bad Banking?" in Boris Pleskovic and Joseph Stiglitz (eds.), Annual World Bank Conference on Development Economics, Washington, DC: The World Bank, 1996, 79-104.

Caprio, Gerard and Daniela Klingebiel, Luc Laeven and Guillermo Noguera, "Banking Crisis Database," In Patrick Honohan and Luc Laeven (eds.), Systemic Financial Crises, (Cambridge: Cambridge University Press, 2005).

Demirgüç-Kunt, Asli and Enrica Detragiache, "Financial Liberalization and Financial Fragility," in Boris Pleskovic and Joseph Stiglitz (eds.) Annual World Bank Conference on Development Economics 1998, (Washington, DC: World Bank, 1999).

Diaz-Alejandro, Carlos, "Stories of the 1930s for the 1980s," in Pedro Aspe Armella, Rudiger Dornbusch, and Maurice Obstfeld, eds., Financial Policies and the World Capital Market: The Problem of Latin American Countries, (Chicago: Chicago University Press for the NBER, 1983), 5-40.

Diaz-Alejandro, Carlos, “Goodby Financial Repression, Hello Financial Crash,” Journal of Development Economics 19, 1985.

Eichengreen, Barry, "Trends and Cycles in Foreign Lending," in Horst Siebert, ed., Capital Flows in the World Economy (Morh: Tubingen, 1991), 3-28.

Fisher, Irving,

Flandreau, Marc, Flores, Gaillard, Nietto, “The End of Gatekeeping: Underwriters and the Quality of Sovereign Bond Markets, 1815-2009" in Lucrezia Reichlin and Kenneth D. West (eds) 2010 NBER International Seminar on Macroeconomics 
2009," (Chicago: University of Chicago Press for National Bureau of Economic Research, 2009).

Flandreau, Marc and Frederic Zumer, The Making of Global Finance, 1880-1913, (Paris: OECD, 2004.)

Gorton, Gary, "Banking Panics and Business Cycles," Oxford Economic Papers, 1988, 40, pp. 751-81.

Haberler, Gottfried, Prosperity and Depression: A Theoretical Analysis of Cyclical Movements (Geneva: League of Nations, 1937).

Kaminsky, Graciela L. and Carmen M. Reinhart, "The Twin Crises: The Causes of Banking and Balance of Payments Problems", American Economic Review, Vol.89 No.4, June 1999, 473-500.

Kaminsky, Graciela, Carmen M. Reinhart and Carlos A.Végh "When It Rains, It Pours: Procyclical Capital Flows and Policies", with. in Mark Gertler and Kenneth S. Rogoff, eds. NBER Macroeconomics Annual 2004, (Cambridge, Mass: MIT Press, 2004), 11-53

Kindleberger, Charles P., Manias, Panics and Crashes: A History of Financial Crises (New York: Basic Books, 1989).

Laeven, Luc and FabianValencia, "Resolution of Banking Crises: The Good, The Bad, and The Ugly," IMF Working Paper, 2010.

League of Nations, Statistical Yearbook: 1926-1944. All issues. (Geneva: League of Nations, various years).

League of Nations, World Economic Survey: 1926-1944. All issues. (Geneva: League of Nations, various years).

Marichal, Carlos, A Century of Debt Crises in Latin America: From Independence to the Great Depression, 1820-1930, (Princeton: Princeton University Press, 1989).

Obstfeld, Maurice, and Alan M. Taylor. Global Capital Markets: Integration, Crisis, and Growth. Japan-U.S. Center Sanwa Monographs on International Financial Markets (Cambridge: Cambridge University Press, 2004.)

Reinhart, Carmen M., Jacob Kirkeegard and Belen Sbrancia, "Financial Repression Redux”, Finance and Development, Vol. 48 No.2, June 2011.

Reinhart, Carmen M. and Vincent R. Reinhart, "Capital Flow Bonanzas: An Encompassing View of the Past and Present," in Jeffrey Frankel and Francesco 
Giavazzi (eds.) NBER International Seminar in Macroeconomics 2008, (Chicago: Chicago University Press for the NBER, 2009). 1-54

Reinhart, Carmen M. and Rogoff, Kenneth S., This Time is Different: Eight Centuries of Financial Folly (Princeton: Princeton Press, 2009).

Reinhart, Carmen M. and Rogoff, Kenneth S., "From Financial Crash to Debt Crisis," American Economic Review, Vol. 101, No. 5, August, 2011, 1676-1706.

Reinhart, Carmen M. and Rogoff, Kenneth S., A Decade of Debt, Policy Analyses in International Economics 95 (Washington DC: Peterson Institute for International Economics, September 2011).

Shiller, Robert, Irrational Exuberance (Second Edition). (Princeton: Princeton University Press, 2005).

Velasco, Andres. "Financial and Balance-of-Payments Crises." Journal of Development Economics, October 1987, 27(1/2), 263-83.

Winkler, Max, Foreign Bonds: An Autopsy, (Philadelphia: Roland Sway Co., 1933).

Wynne, William H. State Insolvency and Foreign Bondholders: Selected Case Histories of Governmental Foreign Bond Defaults and Debt Readjustments Vol. II (London: Oxford University Press, 1951). 